\title{
ANALISIS TATA LETAK DALAM PERSPEKTIF RITEL
}

\author{
Ria Arifianti \\ Departement of Business Administrative Science \\ Faculty of Social and Political Sciences University of Padjadjaran \\ Email : r.arifianti@unpad.ac.id.ria_arifianti@yahoo.co.id
}

\section{ABSTRACT}

Layout strategies undertaken to generate profits, and to provide comfort for visitors. Despite the fact that so run smoothly. This can be seen from the customer complained about the layout made by the company. They complained of the board were not clear and the high placement so that makes them confused for mencarai desired goods

The approach taken in this study is a qualitative approach. The research method is descriptive method. Technique of collecting data using study of literature and field. Field studies using observation and interviews.

The research results that Retail Modern retail use this type of layout. The arrangement is based layout to provide convenience for consumers when shopping. Other than that a good layout. Placement will impact and improve competitiveness. The advice given is a clear indication of the existence of the placement of goods, so as not to confuse consumers when shopping

Keywords : Modern Retail, Lay out Strategy

ANALISIS TATA LETAK DALAM PERSPEKTIF RITEL

\begin{abstract}
ABSTRAK
Strategi tata letak dilakukan untuk menghasilkan keuntungan, dan untuk memberikan kenyamanan bagi pengunjung. Meskipun pada kenyataannya tidak begitu berjalan dengan lancar. Hal ini terlihat dari pelanggan mengeluhkan tata letak yang dilakukan oleh perusahaan. mereka mengeluhkan papan petunjuk yang tidak jelas dan tinggi penempatannya sehingga membuat mereka kebingungan untuk mencarai barang yang diinginkan Pendekatan yang dilakukan dalam penelitian ini adalah pendekatan kualitatif, yaitu penelitian yang dilakukan secara induktif untuk memperoleh data yang bersifat menyeluruh atau holistic dan mendalam. Metode penelitiannya adalah metode deskriptif. Teknik pengumpulan datanya menggunakan observasi, dan wawancara mendalam. Hasil penelitian mennujukkan bahwa Ritel Modern menggunakan jenis tata letak ritel. Penataan tata letak didasarkan untuk memberikan kenyamanan bagi konsumen ketika berbelanja. Selain daripada itu penempatan layout yang baik akan memberikan dampak dan meningkatkan daya saing. Adapun saran yang diberikan adalah Adanya petunjuk yang jelas tentang penempatan barang, sehingga tidak memusingkan konsumen ketika berbelanja
\end{abstract}

Kata kunci : Ritel modern, strategi tata letak 


\section{PENDAHULUAN}

Bisnis ritel merupakan keseluruhan aktivitas penjualan barang atau jasa secara langsung kepada konsumen yang digunakan untuk memenuhi kebutuhan hidupnya. Untuk dapat memenuhi hal tersebut dibutuhkan suatu teknologi dan strategi yang dapat memudahkan pelayanan, proses, serta pengantaran layanan.

Keberadaan ritel modern berdampak bagi produsen, perusahaan dan pemerintah. Sudut produsen dan perusahaan adalah meningkatkan kapasitas pemasaran para distributornya dan pelaku terkait, tetapi pada sisi persaingan usaha memberikan dampak negatif bagi pengecer kecil. Di sisi lain timbulnya ritel memberikan dampak positif bagi pemerintah terutama dalam pendapatan perkapitanya.

Ritel modern semakin lama semakin berkembang. Hal ini mendorong persaingan dunia bisnis yang sangat ketat. Kondisi ini terjadi karena adanya kecenderungan ritel modern dijadikan sarana untuk bersantai yang sangat dibutuhkan oleh masyarakat kota, karena mudah dijangkau tanpa banyak mengorbankan waktu. Selain itu Ritel Modern merupakan tempat yang nyaman dalam melakukan kegiatan jual beli atau bertransaksi. (Edwin Japarianto, 2010: 76).

Oleh karena itu untuk mewujudkan hal tersebut, maka para pengusaha dalam bisnis ritel berusaha mengembangkan strateginya khususnya di bidang operasi untuk dapat menjaring konsumen berbelanja. Salah satunya strategi yang digunakan adalah strategi tata letak. Strategi ini dilakukan untuk menjaring konsumen atau pelanggan. Para pengusaha mencoba membuat tata letak yang dinamis dan dapat memberikan kenyamanan bagi pelanggan. Hal ini dilakukan untuk mempertahankan keberadaan ritel sendiri maupun memberikan kemudahan bagi konsumen dalam mencari barang yang diinginkan.(Ria Arifianti, 2014)

Para pengelola ritel menata produknya berdasarkan kesepakatan para supplier. Dalam hal ini mereka memperkenalkan produk baru yang akan meningkatkan keingintahuan konsumen untuk mencoba sesuatu yang baru.

Tetapi dalam kenyataannya banyak yang dikeluhkan konsumen tentang tata letak ini, yaitu mereka kadangkala kesulitan untuk mencari barang yang diinginkan karena tidak ada petunjuk jelas tentang letak barang yang diinginkan. Kalaupun ada metreka tidak pernah melihat ke arah nama letak barang yang diinginkan karena letaknya yang sangat tinggi.

Hal ini dapat mendorong keuntungan bagi perusahaan dalam segi finansial. Oleh karena itu penulis mencoba mengangkat tema berkaitan dengan Strategi tata letak yang dilakukan oleh Ritel Modern.

\section{Identifikasi Masalah}

Bagaimanakah Strategi Tata Letak di Ritel Modern.

\section{Tujuan Penelitian}

Untuk mengkaji dan menganalisis tata letak yang digunakan di Ritel Modern.

\section{TINJAUAN PUSTAKA}

\section{Konsep Tata Letak (Layout)}

Penentuan tata letak (layout) meliputi pengaturan letak mesin-mesin, bahan-bahan, personalia, perlengkapan untuk operasi, dan semua peralatan dan fasilitas untuk terlaksananya proses produksi yang lancar \& efisien. Desain layout harus dirancang untuk memungkinkan perpindahan yang ekonomis dari orang-orang dan bahan-bahan dalam berbagai proses dan operasi perusahaan. Penentuan layout/tata letak fasilitasfasilitas produksi ini erat hubungannyadengan pendirian bangunan gedung/pabrik.

Penentuan tata letak merupakan suatu langkah atau keputusan penting yang menentukan efisiensi sebuah operasi jangka panjang. Tata letak mempunyai dampak strategis karena menentukan daya saing perusahaan dalam hal kapasitas, proses, fleksilitas, biaya, dan kualitas lingkungan kerja, kontak pelanggan, seta citra perusahaan. Tata letak yang efektif dapat membantu organisasi mencapai suatu strategi yang menunjang diferensiasi, biaya rendah, atau respon yang cepat. (Heizer, Render, 2004 :450)

Tata letak yang tepat, akan memberikan kontribusi terhadap peningkatan produktivitas perusahaan. Hal ini akan memperlancar arus produksi/jasa yang akan diproses, mulai sejak disiapkan dan diserahkan ke dalam pemrosesan sampai produk/jasa akhir, Di samping itu, karyawan dapat bekerja secara leluasa, aman dan 
jauh dari tekanan perasaan. (Haming, Nurnajamuddin. 2011: 433)

Tujuan dari penempatan tata letak ini adalah meminimumkan material handling cost, meningkatkan efisiensi utilisasi ruangan, meningkatkan efisiensi utilisasi tenaga kerja pabrik, mengurangi kendala proses, dan memudahkan komunikasi dan interaksi antara para pekerja, pekerja dengan supervisornya, dan antara pekerja dengan para pelanggan perusahaannya (Russel dan Taylor (2001), Chase., Richard, Aquilano., Jacobs (2001), Dervitsiotis (1981), dan (Haming, Nurnajamuddin. 2011 : 442), Ria Arofianti (2014).

Desain tata letakpun menurut Heizer, dan Render (2004: 450), Ria Arifianti (2014) harus mempertimbangkan bagaimana dapat mencapai :

1. Utilisasi ruang, peralatan, dan orang yang lebih tinggi.

2. Aliran informasi, barang, atau orang yang lebih baik.

3. Moral karyawan yang lebih baik, juga kondisi lingkungan kerja yang lebih aman.

4. Interaksi dengan pelanggan lebih baik.

5. Fleksibilitas (bagaimana kondisi tata letak yang ada sekarang, tata letak tersebut akan perlu dirubah).

Selain daripada itu, tata letak (Render dan Jay, 2001) dan (Haming, Nurnajamuddin. 2011: 433) dapat membantu perusahaan dalam mencapai :

1. Pemanfaatan yang lebih efektif atas ruangan, peralatan, dan manusia ;

2. Arus informasi, bahan baku, dan manusia yang lebih baik;

3. Lebih memudahkan konsumen ;

4. Peningkatan moral karyawan dan kondisi kerja yang lebih aman.

Intinya, tata letak ini digunakan untuk mengembangkan tata letak yang ekonomis dan dapat membantu pencapaian keempat tersebut dengan memenuhi kebutuhan perusahaan untuk beroperasi secara efektif, efisien, ekonomis, dan produktif.

Pada umumnya perencanaan tata letak dan modifikasinya diperlukan setiap perusahaan.
Kebutuhan modifikasi ini disebabkan oleh beberapa faktor, yaitu: (Haming, Nurnajamuddin. 2011: 442)

1. Terjadinya perubahan desain produk secara terus menerus.

2. Adanya perubahan permintaan.

3. Kemungkinan penggantian fasilitas agar selalu baru.

4. Adanya penambahan produk baru.

5. Adanya kondisi lingkungan kerja yang tidak memuaskan

6. Resiko kecelakaan kerja dalam proses produksi

7. Kebutuhan akan penghematan biaya

8. Mendukung pergeseran/perluasan lokasi pasar produk perusahaan.

\section{Tipe-Tipe Tata Letak}

Tipe tata letak terbagi menjadi enam pendekatan (Heizer, Render, 2004 :451) :

1. Tata letak dengan posisi tetap - memenuhi persyaratan tata letak untuk proyek yang besar dan memakan tempat seperti proses pembuatan kapal laut dan gedung.

2. Tata letak yang berorientasi pada proses berhubungan dengan produksi dengan volume rendah, dan bervariasi tinggi (job shop atau produksi terputus).

3. Tata letak kantor - menempatkan pekerja, peralatan mereka, dan ruangan/kantor yang melancarkan aliran informasi.

4. Tata letak ritel - menempatkan rak-rak dan memberikan tanggapan atas perilaku pelanggan.

5. Tata letak gudang - melihat kelebihan dan kekurangan antara ruangan dan system penanganan bahan.

6. Tata letak yang berorientasi pada produk mencari utilisasi karyawan dan mesin yang paling baik dalam produksi yang kontinu atau berulang.

Tipe tata letak di atas dikatakan tata letak tradisional, dan dalam kenyataannya sudah tidak memadai. Sehingga para manajer operasi mengembangkannya. Dan disesuaikan dengan kondisi sekarang. Dalam tata letak modern, telah 
diintegrasikan dengan komputerisasi baik dari segi mesin maupun peralatan produksi. Oleh karena itu tata letak tradisional telah mengalami perubahan dan menjadi lebih fleksibel (disesuaikan dengan keinginan pasar atau kondisi saat ini). Sehingga tata letak tradisional menjadi dinamis dan tidak kaku lagi.

Sedangkan tipe layout modern menurut Russel dan Taylor (2001), Chase., Richard, Aquilano., Jacobs (2001), Render dan Heizer (2001), serta Krajewski dan Ritman (1987), Haming, Nurnajamuddin (2011 : 462-467) mengemukakan bentuk dasar tata letak yang disebutkan sebelumnya dikembangkan menjadi tata letak modern yang disebut Hybride layout (tata letak hibrida). Tata letak hibrida ini dibedakan menjadi : a. tata letak cellular (cellular layout) yaitu mesin dan peralatan produksi yang dibutuhkan untuk mengerjakan suatu produk dikelompokkan dalam suatu machine cell. Tipe ini merupakan pengembangan dan campuran dari tata letak produk dan tata letak proses.

b. Flexible manufacturing system, merupakan penyempurnaan tata letak sebelumnya yang mengintegrasikan mesin yang digunakan dalam pengolahan dengan alat material handling yang otomatis. Dan c mixed-model assembly lines, adalah suatu tata letak lini yang didesain untuk membuat lebih dari satu jenis model atau berbagai jenis produk.

\section{METODE PENELITIAN}

\section{Desain Penelitian}

Pendekatan yang dilakukan dalam penelitian ini adalah pendekatan kualitatif, yaitu penelitian yang dilakukan secara induktif untuk memperoleh data yang bersifat menyeluruh atau holistic dan mendalam. Selain itu desain penelitian ini bersifat terbuka, artinya dalam kurun waktu tertentu dijumpai aspek yang penting yang harus dicakup dalam penelitian, meskipun tidak terduga sebelumnya.

Penelitian kualitatif ini dilaksanakan dengan menggunakan pendekatan studi kasus. Studi kasus adalah suatu inquiri empiric yang menyelidiki fenomena di dalam konteks kehidupan nyata

\section{Teknik Pengumpulan Data}

Teknik pengumpulan data menggunakan:
1. Studi Dokumentasi yaitu peneliti melakukan pengumpulan data dengan menggunakan literature baik berasal dari buku maupun jurnal.

2. Observasi, yaitu teknik pengumpulan data dengan melakukan pengamatan dan pencatatan secara langsung pada objek yang diteliti. Observasi dilakukan dengan mengamati kegiatan di Hypermarket, Supermarket dan Minimarket Kegiatan ini dilakukan pada pukul 12. Hal ini dilakukan karena banyaknya pengunjung yang datang. Waktu pengamatan sekitar 30 menit sampai 60 menit. Pemilihan tempat hanya 3 dikarenakan tempat yang bersangkutan banyak pengunjungnya dan sangat kondusif untuk dilakukan observasi. Selain itu mobilitas pengunjungnya sangatlah tinggi.

3. Wawancara mendalam melalui tanya jawab dan dialog dengan pihak yang berkepentingan/berwenang dari institusi/perusahaan terkait, untuk mendapatkan gambaran umum mengenai perusahaan. Wawancara yang digunakan dalam penelitian ini adalah dengan menggunakan teknik wawancara langsung. Informasi yang utama di dapat dari pengelola, Ritel Modern. Produsen dan dari para konsumen/pelanggan yang sedang berbelanja. Mereka memberikan informasi yang sangat lengkap dalam penelitian ini. Wawancara dilakukan kepada 3 narasumber. Pertama, wawancara kepada pertama konsumen mengenai: keluhan atau masalah tentang layout yang ada di Ritel Modern. Wawancara kepada konsumen dilakukan terhadap 5 orang per Supermarket, Minimarket dan Hypermarket. Waktu wawancara sekitar 30 menit. Kedua, wawancara terhadap manajer hypermarket dengan mengajukan pertanyaan tentang strategi tata letak (layout) telah dilaksanakan oleh mereka dan cara mengatasi hal-hal yang dikeluhkan oleh konsumen. Lamanya wawancara sekitar 1 jam sampai dengan 2 jam. Ketiga, produsen hanya untuk memastikan saja tentang keterlibatan mereka dalam penataan tata letak.

\section{Teknik Analisa Data}

Analisa Data pada penelitian ini mengacu pada model analisis data kuantitatif dari Miles dan Huberman. Menurut Miles dan Hubermen 
yang dikutip Sugiono (2011: 91), analisis dapat dilakukan dengan tiga langkah :

\section{Data Reduction}

Reduksi data berarti merangkum, memilih hal-hal pokok, memfokuskan pada hal-hal penting, dicari tema dan polanya. Dengan demikian data yang direduksi akan memberikangambaran yang lebih jelas dan mempermudah peneliti untuk melakukan pengumpulan data selanjutnya serta mencarinya bila diperlukan.

\section{Data Display (Penyajian Data)}

Setelah data direduksi, langkah selanjutnya adalah menyajikan data tersebut untuk mempermudah dalam memahami apa yang terjadi dan merencanakan kerja selanjutnya berdasarkan apa yang telah dipahami tersebut. Dalam penelitian kualitatif, penyajian data dapat dilakukan dalam bentuk uraian singkat, bagan, hubungan antar kategori, flowchart, dan sejenisnya.Dalam hal ini yang sering banyak digunakan untuk menyajikan data dalam penelitian data dalam penelitian kualitatif adalah dengan teks yang bersifat naratif.

3. Conclusing drawing/verification (menarik kesimpulan/verifikasi)

Kesimpulan awal yang dikemukakan masih bersifat sementara dan akan berubah bila tidak ditemukan bukti-bukti kuat yang mendukung pada tahap awal didukung bukti-bukti valid dan konsisten saar peneliti kembali ke lapangan mengumpulkan data, maka kesimpulan yang kredibel.

Sejalan dengan penjelasan di atas, kesimpulan dalam penelitian kualitatif mungkin dapat menjawab rumusan masalah yang dirumuskan sejak awal, tetapi mungkin saja tidak, karena seperti yang dikemukakan bahwa masalah dan rumusan masalah dalam penelitian kualitatif bersifat sementara setelah peneliti berada di lapangan.

\section{Pengujian Kredibilitas Data}

Data-data temuan dalam penelitian kualitatif dinyatakan valid apabila tidak ada perbedaan antara yang dilaporkan peneliti dengan apa yang sesungguhnya terjadi pada objek yang diteliti. Untuk itu diperlukan uji nilai kebenaran (uji kredibilitas) terhadap data yang didapatkan. Pengujian kredibilitas data penelitian dengan cara:

1. Triangulasi
Pengujian kredibilitas data penelitian menggunakan triangulasi teknik dan triangulasi sumber data. Triangulasi teknik menggunakan cara dengan menanyakan hal yang sama dengan teknik yang berbeda. Yaitu dengan cara wawancara, observasi dan dokumentasi. Triangulasi sumber data dilakukan dengan cara menanyakan hal yang sama melalui sumber yang berbeda. Dalam hal ini sumber datanya manajer Ritel Modern (Minimarket, Supermarket dan Hypermarket)

\section{Diskusi dengan tim peneliti}

Hasil penelitian ini didiskusikan dengan tim peneliti. Melalui diskusi ini banyak mendapat masukan, pertanyaan berkenaan dengan data yang didapatkan. Dengan demikian datanya akan menjadi lengkap dan lebih kredibel.

\section{HASIL DAN PEMBAHASAN}

Ritel modern terbagi menjadi beberapa jenis. Dalam pembahasan ini menitikberatkan pada 3 jenis ritel modern yaitu Minimarket, Supermarket dan Hypernmarket. Karakteristik dasar unsur ritel tersebut dapat dijelaskan sebagai berikut :

Pertama, Minimarket memiliki variasi dan jenis produk yang terbatas. Luas lantai ritel jenis ini berukuran kurang dari 350 meter persegi dan merupakan pasar swalayan mini yang menjual hanya lini terbatas dari berbagai produk kebutuhan sehari-hari yang perputarannya relatif tinggi. Toko ini ditujukan kepada konsumen yang membutuhkan pembelian dengan cepat tanpa harus mengeluarkan upaya yang besar dalam mencari produk-produk yang diinginkannya. Produk-produk yang dijual biasanya ditetapkan dengan harga yang lebih tinggi daripada supermarket.

Kedua, Supermarket melayani penjualan makanan, daging, serta produk-produk makanan lainnya, serta melakukan pembatasan penjualan terhadap produk-produk non makanan, seperti produk kesehatan, kecantikan dan produk-produk umum lainnya. Luas lantai ritel ini berukuran $1.500-3000 \mathrm{~m}^{2}$. Jumlah barang yang ditawarkan 8.000 sampai dengan 12,000 item.

Ketiga, Hypermarket merupakan supermarket yang memiliki luas antara lebih dari 18.000 meter persegi dengan kombinasi produk makanan 6070 persen dan produk-produk umum 30-40 persen. Barang yang dijual di Hypermarket 
meliputi produk makanan, perkakas (hardware), peralatan olahraga, furnitur, perlengkapan rumah tangga, komputer, elektronik, dan sebagainya. Pendekatan dasar dari hypermarket adalah tampilan besar dan penanganan yang minim oleh pelayan toko, dengan diskon yang diberikankepada pelanggan yang bersedia membawa alat-alat rumah tangga dan mebel yang berat keluar dari toko. Hypermarket juga menyediakan kafetaria, bank, bakery, dan salon kecantikan. Dengan demikian, hypermarket adalah toko eceran yang mengkombinasikan pasar swalayan dan pemberi diskon. Penekanannya adalah one stop shopping yaitu tempat menjual barang yang dibutuhkan semuanya ada di dalam toko tersebut.

Ritel modern (Minimarket, Supermarket, Hypermaret) mempunyai bentuk tata letak ritel. Tata letak ritel menempatkan rak-rak dan memberikan tanggapan atas perilaku pelanggan. Rak-rak tersebut diletakkan di lorong-lorong sehingga memudahkan konsumen untuk berbelanja. Penempatan tata letak berkaitan dengan: (Heizer, Render, 2004 : 466-467)

1. Penempatan barang-barang yang sering dibeli oleh pelanggan/konsumen di sekitar batas luar toko. Biasanya penempatan produk susu atau berbahan dasar susu di tempatkan dengan produk roti maupun kue. Semua ritel modern menggunakan sistem ini.

2. Menggunakan lokasi yang strategis untuk barang-barang yang menarik dan memberikan keuntungan besar, seperti penempatan peralatan rumah tangga, kosmetik, sampo. Minimarket menempatkan peralatan rumah tangga seperti kemoceng atau sapu di belakang. Hal ini juga digunakan oleh Supermarket maupun Hypermarket. Selain daripada itu menempatkan barangbarang yang ringan seperti permen, coklat, baterai, rook di tempat-tempat yang terjangkau atau di tempatkan di depan atau di dekat kasir. Hal ini bertujuan untuk membuat orang berbelanja.

3. Mendistribusikan produk yang kuat yaitu barang-barang yang menjadi alasan pengunjung berbelanja, pada kedua sisi lorong, dan meletakkannya secara tersebar untuk menjadikan pengunjung melihat lebih banyak barang yang lain. Biasanya berkaitan dengan barang yang mudah dikenali dan berukuran kecil. Sebagai contoh, penempatan dekat Kasir berkaitan dengan rokok, baterai, permen, coklat dan sebagainya. Penempatan ini dilakukan dalam bentuk ritel apapun.

4. Menggunakan lokasi di ujung lorong karena memiliki tingkat eksposur yang tinggi. Biasanya ujung lorong ini berkaitan dengan penempatan barang yang akan diberikan potongan harga khusus. Sebagai contoh penempatan barang yang akan diberikan potongan harga ditempatkan di depan dengan adanya informasi berupa leaflet dan gondola. Sehingga konsumen dapat melihat dengan jelas.

5. Sampaikan misi toko dengan memilih posisi bagian yang akan menjadi perhentian pertama bagi pelanggan. Sebagai contoh, Di Hypermart, biasanya penempatan pertama berkaitan dengan barang yang mempunyai potongan harga tinggi. Sedangkan Carrefour, penempatan atau posisi bagian pertama perhentian adalah barang-barang yang mengalami diskon. Sedangkan Giant, berkaitan dengan makanan. Sedangkan Supermarket juga menempatkan barang di depan adalah barang yang mengalami penurunan harga.

Penempatan barang juga disesuaikan dengan permintaan supplier. Hal ini berkaitan dengan pendaftaran item baru (listing fee). Dalam istilah tata letak dinamakan biaya slotting. Biaya slotting (slotting fees) adalah biaya yang dibayar produsen/supplier untuk menempatkan produk baru mereka pada rak di rantai ritel atau supermarket. (Heizer, Render, 2004: 466-467)

Dilihat dari sudut hypermarket, listing fee merupakan suatu kompensasi yang harus dibayarkan supplier karena diberikannya kesempatan/peluang bagi item/barang yang bersangkutan untuk dijual sebagai assortment toko ritel tersebut. Mereka selalu menekankan kepada supplier untuk memandang listing fee ini sebagai bagian dari investasi yang harus ditanamkan. Biasanya penempatannya berada di depan atau dekat dengan kasir.

Pembayaran listing fee itu untuk tiap item cukup dibayarkan sekali saja dan berlaku untuk seluruh toko, serta dengan tarif yang wajar, maka pihak supplier pun dapat mengganggapnya sebagai hal yang wajar pula. Kisarannya berkisar Rp. 1.000.000 per item. Tetapi biaya ini bisa berubah naik atau turun tergantung pada kebijakan hypermarket tersebut. Namun ketika listing fee ini dikenakan untuk setiap item dan 
setiap kali buka toko baru dengan tarif yang semakin besar, maka hal ini dapat dianggap di luar batas kewajaran. Tetapi di Supermarket ada yang tidak menggunakan Listing fee, karena mereka hanya menggunakan gondola untuk memperkenalkan produk baru.

Dalam tata letak juga mempertimbangkan:

Pertama, kondisi yang berkenaan dengan lingkungan seperti misalnya pencahayaan, suara, bau dan suhu. Ritel menggunaan pencahayaan yang tidak menyolok mata dengan menggunakan lampu neon bukan lampu yang dapat merusak mata. Suara di Ritel ini berkaitan dengan lagulagu yang diperdengarkan kepada konsumen. Lagu ini berasal dari radio atau compact disk yang mereka perdengarkan kepada konbsumen dengan tujuanh untuk memberikan kenyamanan.

Selain pencahayaan lampu, penempatan barang pun dilihat dari warna yang akan ditempatkan. Penempatan barang yang mempunyai warna cerah ditempatkan di rak atas sedangkan barang yang mempunyai warna gelap ditempatkan di bawah. Hal ini bertujuan untuk menjaga penglihatan konsumen.

Dalam ruangan pengelola menggunakan pewangi ruangan untuk menghindarkan bau yang tidak sedap. Selain daripada itu pengelola mengatur suhu udara di dalam toko. Toko menggunakan $\mathrm{AC}$ untuk memberikan kesejukan kepada konsumen.

Kedua, tata letak yang luas dan mempunyai fungsi berkaitan dengan sirkulasi pelanggan, karakteristik lorong (lebar, arah, sudut, dan jarak antar rak), serta pengelompokkan produk. Dalam menata barang yang dijual pengelola ritel membuat lorong-lorong untuk memudahkan konsumen berbelanja. Hal ini dilakukan untuk memudahkan seseorang untuk berbelanja. Dengan lorong yang luas, membuat konsumen leluasa untuk melakukan kegiatan berbelanja. Mereka mempunyai sensasi tersendiri ketika mengitasi lorong-lorong yang disediakan.

Khusus Minimaret, lorong-lorong yang dibuat tidak terlalu panjang. Hal ini terjadi karena barang yang ditawarkan tidak terlalu banyak. Sehingga konsumen yang datang ke Minimarket membeli barang yang dibutuhkan secara cepat.

Selain daripada itu Hypermarket melakukan perubahan atau pergeseran tata letak, yang bertujuan untuk memberikan kesegaran, kesan yang baru dan ekslusif bagi pengunjung.
Pelanggan/konsumen harus bergerak lebih jauh dan berputar untuk mendapatkan semua barang yang dibutuhkan. Dengan adanya pemindahan tempat pemajangan dan perubahan tampilan pajangan barang di rak penjualan, diharapkan untuk mempengaruhi pandangan konsumen sehingga dapat menciptakan persepsi bagi para konsumen, minimal ada anggapan bahwa barang yang lama sudah habis terjual dan barang baru di peroleh di tempat pemajangan lainnya. (Haming, Nurnajamuddin. 2011: 460)

Hal ini menurut konsumen/pelanggan merupakan sesuatu yang menarik. Mereka bisa merasakan kenyamanan dan keleluasaan untuk berbelanja. Hal ini menimbulkan kesan tersendiri untuk mereka. Mereka merasa berpetualangan dan merasa tidak terlalu diburu oleh waktu dalam berbelanja. Tetapi ada juga yang beranggapan mereka tidak menyukai perubahan tersebut karena dapat memberikan kesulitan bagi mereka.

Berdasarkan hal tersebut, Ritel Modern biasanya melakukan perubahan tempat atau penempatan barang berkaitan dengan barang yang sedang melakukan promosi. Biasanya penempatannya berada di dekat pembayaran.

Dalam penempatan makanan pun, Khusus Hypermarket membuat restoran tersendiri yang berada di dalam toko tersebut. Biasanya penempatannya berada di belakang atau di samping dekat dengan penjualan sayuran segar atau makanan tradisional, ataupun berkaitan dengan roti. Supermarket tidak menempatkan kursi maupun meja, tetapi menawarkan makanan matang.

Sedangkan Minimaret juga mempunyai tata letak yang berbeda dengan Supermarket ataupun Hypermarket. Sebagian Minimarket menempatkan meja dan kursi di teras depan toko atau di dalam toko sebelum penempatan barang. Ini bertujuan untuk memberikan tempat kepada konsumen untuk menikmati hidangan cepat saji seperti kopi, susu atau mie roti yang disajikan hangat.

Ketiga berkaitan dengan tanda-tanda, symbol, yang merupakan karakteristik desain. Untuk memudahkan para konsumen mencari barangnya, biasanya pengelola mencantumkan petunjuk atau panah atau menempatkan tulisan pada papan yang ditempel di atas atau pada rak lorong tersebut. Hal ini dilakukan untuk memudahkan konsumen/pelanggan dalam 
mencari barang yang diinginkan. Tetapi petunjuk tersebut ditempatkan atau menempel pada bagian atas rak. Sehingga hal ini kadangkala menyulitkan konsumen/pelanggan. Kadangkala konsumen hanya mengitari atau mencari-cari barang berkali-kali dengan mengitari lorong tersebut. Ini dikarenakan konsumen tidak mau menanyakan letak barang yang diinginkan kepada pegawai.

\section{SIMPULAN}

\section{Simpulan}

Tata letak (Layout) Ritel Modern menggunakan jenis tata letak (layout) ritel. Penempatan barang juga disesuaikan dengan permintaan supplier. Para supplier membayar listing fee untuk menempatkan sesuai keinginan. Tetapi tidak semua menggunakan listing fee tapi menggunakan gondola,

Dalam penempatan barang digunakan dark light. Artinya penempatan barang dilihat dari pencahayaan. Penempatan barang di atas untuk warna terang dan di bvawah warna gelap. Hal ini bertujuan untuk menjaga pandang mata pembeli.

Selain daripada itu adanya lorong-lorong untuk memudahkan konsumen dalam mencari barang yang diinginkan.

Penataan Tata letak (layout) didasarkan untuk memberikan kenyamanan bagi konsumen ketika berbelanja. Selain daripada itu penempatan tata letak yang baik akan memberikan dampak dan meningkatkan daya saing.

\section{Saran}

1. Pengelola lebih memperhatikan petunjuk tentang penempatan barang, sehingga akan memudahkan konsumen untuk mencari barang yang diinginkan.

2. Letak petunjuk tempat tdak terlalu tinggi supaya memudahkan konsumen dalam mencari barang yanmg diinginkan

\section{DAFTAR PUSTAKA}

Chase., Richard B., N.J. Aquilano., F.R. Jacobs. 2001. Operations Management for Competitive Advantage, $9^{\text {th }} \mathrm{Ed}$. Mc. Graw-Hill Irwin, Boston Burr Ridge.

Dervitsiotis, Kostas N., 1987. Operations Management. Mc. Graw Hill International Book Company. Aukland.

Japarindo. 2010. Analisa Faktor Type Hedonic Shopping Motivation dan aktor

Pembentuk Kepuasan Tourist Shopper di Surabaya. Jurnal Manajemen dan Kewirausahaan. Universitas Kristen Petra. Hal 76-85

Haming, Murdifin. Mahfud Nurnajamuddin. 2011. Manajemen Produksi Modern, Operasi Manufaktur dan Jasa. Jakarta. Bumi Aksara.

Hani Handoko, 2000. Dasar-dasar Manajemen Produksi Dan Operasi, Edisi 1, BPFE Yogyakarta.

Heizer Render, 2006. Operations Management, 8th Edition, Pearson International Education.

Henky Njoto Widjaja. 2008. Mengungkap Sukses Hypermarket Asing.

Krajewski, Lee, J. Lary P. Ritzman, 1987. Operation Management Strategy and Analysis. Addition Wesley Publishing Company. Massachusetts.

Render, Barry. Jay Heizer. 2001. PrinsipPrinsip Manajemen Operasi, Diterjemahkan oleh Krenohadi Ariyoto. Jakarta. Penerbit Salemba Empat.

2005. Manajemen Operasi, Edisi Ketujuh, Jakarta. Salemba Empat.

Ria Arifianti. 2014. Hypermarket Layout Analysis In Hypermarket Bandung. (Prosiding Yongsan University - Korea)

Russell, R.S., B.W.Taylor III. 2000. Operation Management Multimedia Version. The Prentice Hall Inc., Upper Saddle River, $\mathrm{Nj}$.

Sapu Jagat, 2010. Menelisik Geliat Bisnis Ritel Modern. Jakarta.

Sugiono. 2011. Metode Penelitian Kuantitatif Kualitatif dan R \& D. Penerbit Alfabeta. Bandung. 